\title{
Reparations for human rights violations: how far back?
}

\author{
by Dinah Shelton
}

There is no single answer to the question 'how far back?' and the legal community needs to identify the appropriate cases and provide the compelling arguments that will lead to the just result.

$\mathrm{N}$ early every person probably has heard the adage 'where there is a right, there is a remedy' (ubi jus ibi remedium), a phrase which suggests that the very notion of a right is inextricable from having an enforceable claim. (See in general, Dinah Shelton's, Reparations in International Human Rights Law (OUP, 1999)). The international law of human rights certainly lists the right to a remedy as one of the rights to be guaranteed in national law. If no domestic remedy is afforded because of lack of access to a competent forum or lack of a basis for reparations in substantive law, a growing number of international procedures allow claims to be brought against the state that committed the wrong.

The issue of reparations for human rights violations has drawn increasing interest in recent years. The UN has studied the problem, appointing a series of special rapporteurs to study aspects of the issue. The Durban World Conference on Racism organised by the United Nations took up the topic. The transitions from repressive to democratic regimes across the continents (South Africa, Latin America, Central and Eastern Europe, Asia) have led successor regimes into difficult discussions with the survivors of human rights violations about the appropriate means to deal with the past. Unresolved claims from the Second World War continue to emerge, while ethnic conflicts demonstrate the dangers of leaving such claims unresolved with the hope that they will be forgotten. There are many ways to categorise reparations claims. I suggest three main divisions:

1. Individual claims. One person is wrongfully arrested and detained; a single factory is illegally confiscated; an individual is prosecuted under a law that conflicts with the state's human rights obligations. These are the cases taken to Strasbourg, or to the Inter-American
Commission and Court, or to one of several UN bodies.

2. Gross and systematic violations. The language is that of the UN, designating a level of violations that can be deemed a breach of the United Nations Charter. These are serious and widespread occurrences in a state: racial segregation in the US or apartheid in South Africa; forced disappearances in Honduras and Argentina; systematic torture in Chile; arbitrary executions in the Philippines; all of the above in some States.

3. Historic injustices. These are claims that pre-date the international law of human rights, in some cases stemming from acts that took place centuries ago. Genocide of indigenous groups in many parts of the Western Hemisphere; brutality during wartime; slavery; religious persecution; the sacking of Constantinople by the crusaders or the burning of the library of Alexandria by the Romans.

All three categories have some elements in common: a perceived wrong or injustice for which the victims, survivors or descendants seek redress. But the reality is very different when examined more closely.

In international law, reparation for human rights violations is a sub-category of the law of state responsibility. According to this body of law, every breach of an international obligation automatically gives rise to a duty to make full reparation, by restitution if possible and by compensation and/or satisfaction if restitution is not possible. The recently completed articles on the law of state responsibility make clear this objective. The goals are to bring the offending state into compliance with the law and to provide compensatory justice to the injured party. Although the rules were drafted for the inter-State 
context, there is language in them stating that they are 'without prejudice' to the obligations that may be owed to non-State actors.

What are the problems?

1. Any international duty to afford reparations depends upon there being a breach of law and generally law is not retroactive. Thus, the European Court of Human Rights does not apply to events that occurred before the date of its entry into force (3 September 1953). Nor can complaints be brought against acts of a State that were committed before the State became a party to the Convention. Of course, the now-accepted idea of 'continuing violations' that applies in the case of disappearances, for example, offers some ability to reach back in time.

2. Reparations are purely compensatory neither exemplary nor punitive. For purely dignitary harms like canceling an election and depriving a people of democratic government, there are no assessable damages. Alternative remedies must be sought.

3. In the absence of a global court of human rights, the existing commissions and committees may make recommendations to the state concerned about appropriate redress, but they may not order remedies.

4. The problem of gross and systematic violations is that the sheer number of violations is too big to make full reparations available to every victim. One study estimates that 170 million died from human rights violations during the twentieth century compared to 33 million in military conflicts. A choice must be made between speed and simplicity of procedure and individualized justice. Various methods have been adapted from one state to another and none are really satisfactory. States attempt, some with more good faith than others, to allocate losses fairly and repair the harm caused, using one or more of the techniques of prosecution, rehabilitation, compensation, symbolic redress and lustration? Debate continues over the question of the scope of international obligations in these cases.

5. Historic injustices. The heart of the current issues lies in the question 'how far back'? An easy answer is 'only as far as the law goes'. If the act was lawful when done, then no reparations are due. But this may be too easy an answer.

\section{THE PROBLEM OF HISTORIC INJUSTICES}

The Secretary-General Kofi Annan of the United Nations has recently commented at the Durban Conference on the link between the past and the present:

'Sometimes (today's) problems are in part the legacy of terrible wrongs in the past - such as the exploitation and extermination of indigenous peoples by colonial Powers, or the treatment of millions of human beings as mere merchandise, to be transported and disposed of by other human beings for commercial gain. The further those events recede into the past, the harder it becomes to trace lines of accountability. Yet the effects remain. The pain and anger are still felt. The dead, through their descendants, cry out for justice. Tracing a connection with past crimes may not always be the most constructive way to redress present inequalities, in material terms. But man does not live by bread alone. The sense of continuity with the past is an integral part of each man's or each woman's identity. Some historical wrongs are traceable to individuals who are still alive, or corporations that are still in business. They must expect to be held to account. The society they have wronged may forgive them, as part of the process of reconciliation, but they cannot demand forgiveness as of right. Far more difficult are the cases where individual profit and loss have been obscured by a myriad of other, more recent transactions, yet there is still continuity between the societies and states of today and those that committed the original crimes. Each of us has an obligation to consider where he or she belongs in this complex historical chain. It is always easier to think of the wrongs one $={ }_{s}$ own society has suffered. It is less comfortable to think in what ways our own good fortune might relate to the sufferings of others, in the past or present. But if we are sincere in our desire to overcome the conflicts of the past, all of us should make that mental effort.'

(Report of the World Conference against Racism, Racial Discrimination, Xenophobia and Related Intolerance, Durban, 31 August - 8 September 2001. A/CONF.189/12 (Part III) Annex II at 7).

He added: "We have seen; in recent decades, some striking examples of national leaders assuming this responsibility, acknowledging past wrongs and asking pardon from - or offering an apology to - the victims and their heirs. Such gestures cannot right the wrongs of the past. They can sometimes help to free the present - and the future from the shackles of the past.

\section{RECENT CASES}

News reports and law journals in recent years have reported numerous claims made by groups seeking reparation for historic injustices, including Holocaust claims, radiation exposure cases, the 'lost generation' of forcibly removed aboriginal children in Australia, Japanese from Latin American interned in the U S during World War II. For specific cases see for example Princz v Federal Republic of Germany, 26 F. 3d 1166 (D.C. Cir.1994); Sampson v Federal Republic of Germany, No.96 C 6242, 1997 WL 583069 (N.D. I11. 1997), aff'd 7th Cir. 23 May 2001; Iwanowa v Ford Motor Co., 67 F. Supp. 2d 424 (D.N.J. 1999); Burger-Fischer $v$ Degussa AG, 65 F. Supp.2d 248 (D.N.J. 1999); Friedman v Union Bank of Switzerland, No. CV-96-5161 (E.D.N.Y. 21 October 1996). The amounts and numbers are enormous. 
- In North American, the amount of Native American lands declined from 138 million acres in 1887 to 52 million acres in 1934. Some 26 million acres were lost through fraudulent transfers. (See Paul Brest and Miranda Oshige, 'Affirmative Action for Whom?' 47 Stan. L. Rev. (1995)). As early as 1851 some effort was made to compensate for the taking of land and the near extermination of many groups through the creation of Native American reserves. In 1946, the federal government created an Indian Claims Commission with jurisdiction to hear and resolve claims arising from the seizure of Indian property and breaches by the United States of its treaties with the Indian nations and tribes. (Act of 13 August 1946, chapter 959, section 1, 60 Stat. 1049 (West 1999)). The Commission was not fully successful and in December 1999, a federal court awarded $\$ 2.5$ billion in reparations for a century of trust fund mismanagement by the US Department of the Interior and Treasury. (Breast \& Oshige, supra at 14). In addition, since 1971, the indigenous Alaskans have received over one billion dollars and 44 million acres of land wrongfully seized through the Alaska Native Claims Settlement Act 197143 U.S.C. section 1601 (1998). The Act was motivated by a political desire to further the Alaskan oil pipeline by settling indigenous land claims. In the non-State sector, the Methodist church apologized to Native Americans in Wyoming for a 1965 post-treaty massacre led by a Methodist minister.

- In 1993, the US Congress apologised to indigenous Hawaiians for the overthrow of the Hawaiian government by the US. (Pub. L. No. 103-150, 107 Stat. 1510,1513 (1993)). In 1995, the legislature committed $\$ 30$ million a year for 20 years to the Hawaiian Homelands Trust. For cases concerning Hawaiian claims see Office of Hawaiian Affairs $v$ State of Hawaii, Civ. No.940205-01; Ka-ai-ai v Drake, Civ. No.92-3742-10 (1st Cir. 1992); Kealoha v Hee, Civ. No.94-0118-1 (1st Cir.).

- As part of the millennium celebrations, Pope John Paul II apologised for the wrongdoings of Roman Catholics during the past two centuries. Elsewhere, the Southern Baptist Convention apologised for its defence of slavery.

- The removal and relocation of more than 100,000 Americans of Japanese ancestry during World War II has been the basis of half a century of litigation and lobbying efforts. Executive Order 9066, calling for the relocation, was upheld by the United States Supreme Court in Korematsu v United States 323 U.S.2 14 (1944). After years of effort to redress what was viewed as an unjust and unconstitutional action, in 1980 Congress established a Commission on Wartime Relocation and Internment of Civilians to review the impact of the order and study the reparations issue under the Japanese Evacuation Claims Act, (Ca.814, 62 Stat. 1231 (1984)). Its report, the Commission found that the Executive Order was not justified by military necessity and the decisions were not driven by military conditions (see Commission on Wartime Relocation and Internment of Civilians, Personal Justice Denied, Part Two: Recommendations (1983)); instead, the causes were race prejudice, war hysteria and a failure of political leadership. As a response, Congress passed the Civil Liberties Act 1988, which required a payment of $\$ 20,000$ to each survivor of the World War II internment camps and an official apology to Japanese Americans as a whole (50 U.S.C. section 1989b-4 (1994)).

- The German Government has paid out $\$ 60$ billion to Holocaust victims since 1952 for state crimes; it also recently created a fund of $\$ 5.2$ billion for acts of companies that used forced labor.

- African Americans were assaulted in the town of Rosewood, Florida in 1923 after false accusations that a black man had sexually assaulted a white woman. Eight blacks were murdered and whites from neighboring towns burned all black homes. Law enforcement stood by and did nothing. In 1993, Florida paid $\$ 2$ million to the survivors of the group who were driven from the town. A fund was set up to compensate later claimants who could prove they had lost property, and a separate scholarship fund offered priority to Rosewood descendants.

- A 1921 race riot in Tulsa Oklahoma has been studied and on February 4, 2000, the Commission recommended to the state legislature that reparations be made to the survivors of the attacks.

- Claims for slave reparations date back to 1774 when Thomas Paine proposed repairing the injuries cause by 'the wickedness of the slave trade.'(See archive of Thomas Paine, Thomas Paine: African Slavery in America, http://www.mediapro.net/cdadesign/paine/afri.html). Redistribution of land was proposed after the Civil War and led to the Freedmen's Bureau Act, July 16, 1866, 14 Stat. 173 (1866), which promised 40 acres and a mule to each former slave. The promised reparations were overturned after the assassination of Lincoln and land given had to be returned. During the 1960 s civil rights movement, the issue resurfaced.

- James Foreman's Black Manifesto demanded reparations from white churches and synagogues for their 'crimes against African Americans.' The manifesto asked for a bank, publishing and printing industries, television networks, a research center, a training center, a welfare rights organization, a defense fund and a university. An African-American Representative in Congress sponsored a bill in Congress in 1989 to study reparations for African Americans and has repeated the proposal in every Congressional session since that time. The proposal has never made it out of committee.

The above claims have been dealt with largely in the political arena. In contrast, lawsuits for reparations for 
historic injustices have not been successful. In Cato v United States, 70 F.3d 1103 (9th Cir.1995) for example, the court rejected slave reparations. It found the existence of treaties between Native Americans and the United States to be an important factor in their reparations, because the treaties created relationship between nations and thus made the situation unique. The court also noted the statute of limitations and sovereign immunity as a basis for denying relief, indicating that the legislature is the appropriate forum to press the claim of slave reparations.

\section{CRITIQUES OF REPARATIONS FOR HISTORIC INJUSTICES}

The debate over reparations for historic injustices has been loud and contentious. Opponents cite to the cost, both in money and social upheaval. It is estimated that if the current 22 million African Americans took up the promised value of 40 acres and a mule the resulting compensation would probably amount to several trillion dollars. These arguments are similar to those that calling for respecting domestic amnesties for violations of human rights in the name of societal reconciliation. Opponents also claim that reparation has occurred, because modern civil rights laws are reparative, especially when they include affirmative action measures.

On a practical level, the identification of specific perpetrators and victims becomes much harder as time and distance increases. With slave reparations, for example, how should the classes of victim and perpetrator be identified - most persons are diverse in their ancestry and may have both slaves and slaveholders among their forbearers. Race is not a scientific concept and identifying those entitled to claim reparations on that basis could be particularly problematic. Some object on principle. Henry Hyde, a Republican Member of Congress, has stated:

'The notion of collective guilt for what people did (200 plus) years ago, that this generation should pay a debt for that generation, is an idea whose time has gone. I never owned a slave. I never oppressed anybody. I don't know that I should have to pay for someone who did generations before I was born.'

(See Kevin Merida, 'Did Freedom Alone Pay a Nation's Debt?' Rep. John Conyers Jr. Has a Question. He's Willing to Wait a Long Time for the Right Answer, Washington Post, 23 November 1999, at C1).

Historical claims thus cannot rationally be based upon the paradigm of individual perpetrator, individual victim, and quantifiable losses; causation of present harm is especially difficult to show. Finally, the calculation of the quantum of damages is almost impossible. All these factors pose formidable obstacles to obtaining reparations through judicial action or even legislation.
Author Eric Yamamoto further argues that it is a mistake to think that reparations will lead to broader societal changes. In his view Japanese redress in US does not appear to have moved society more broadly towards racial justice or against stereotypes, and has not prevented other groups from being targeted as the Japanese were. However, it may be part of a discourse that can move the state to take further actions in its power in favor of new social arrangements that can restructure. The problem is to ascertain whether reparation for historic injustice will heal or create a sense of new injustice and a backlash by those who must pay, reawakening old stereotypes, old injuries and further inflaming mistrust and anger. (See Art Alcausin Hall, 'There is a Lot be Repaired Before We Get to Reparations: A Critique of the Underlying Issues of Race that Impact the Fate of African American Reparations,' 2 Scholar 1 (2000)).

\section{ARGUMENTS SUPPORTING REPARATIONS}

Proponents of reparations point to the symbolic importance of apology and redress. Japanese Americans who were interned suffered lingering harm and bestowal of symbolic reparations fostered long overdue healing for many ' . . . a measure of dignity was restored'. (See Eric Yamamoto, 'Symposium: Racial Reparations: Japanese American Redress and African Claims', 40 Boston College L. Rev. 477, 478 (1998)). Another internee said 'reparations have allowed many of us to put aside our bitterness and constructively reflect upon our responses to the internment.' (Quoted in Michael Honda, 'Japan's War Crimes: Has Justice Been Served?' 21 Whittier L. Rev. 621,622 (2000)). According to him, it succeeded in bringing closure in two infinitely critical ways. First, it stipulated to the truth that the community was innocent and the internment was not justified. Second, it recognised that the community suffered immeasurably and that by paying reparations the United States symbolically accepts the detriment the community suffered (ibid. at 623).

In rebutting the critique about the inability to identify individual victims of distant injustices, proponents argue that reparations are about groups, not individuals. Many base their claims on theories of unjust enrichment, contending that much of today's wealthy individuals and institutions obtained their riches through privilege and suppression, exclusion and discrimination of others.

On the positive side, proponents posit that reparations for historic injustices have a broader purpose and benefit: restructuring the institutions and relationships that underlie the grievance. They seek to address root causes not simply obtain monetary compensation. In international terms, they are seeking reconciliation and looking at social transformation. They argue that post-civil war reconstruction in the US failed precisely because no reparations were implemented. Without land redistribution and economic benefits, 
freedom for slaves left them without possibility of upward movement.

\section{CONCLUSIONS}

Reparation for historic injustice is a political and moral issue, but in most instances is not a legal matter. Almost no such reparations have been awarded through court action; instead almost all have come about through legislation or executive action. Successful legal and political claims seem to rest on similar facts: specific and identifiable government acts in violation of legal norms; still living and identifiable victims; identifiable perpetrators and identifiable injuries suffered over a fixed period of time. These elements were present in the cases of interned Japanese-Americans and the town of Rosewood (in the latter case there were but nine survivors and 145 descendents of the original victims; in addition causation and measure of damages was relatively easy). For the remaining cases of historic injustices, reparation means recasting what claims are legal or resting the claims on moral, ethical and political grounds, in order to healing breaches of larger social policy and repair historic oppression.

Can a legal claim be posited? It may be that a distinction between positive law and natural law, common at the time of slavery and earlier, could provide a foundation for present claims. The argument would assert that the acts were illegal at the time, even if not in positive law. Of course, in some instances - although probably not for slavery in the US - there would still be a problem of laches or stale claims. Significant in this respect is the language agreed to in the final declaration of the Durban World Conference on Racism:

Note the language of Durban:

'We acknowledge that slavery and the slave trade, including the transatlantic slave trade, were appalling tragedies in the history of humanity not only because of their abhorrent barbarism but also in terms of their magnitude, organized nature and especially their negation of the essence of the victims, and further acknowledge that slavery and the slave trade are a crime against humanity and should always have been so, especially the transatlantic slave trade and are among the major sources and manifestations of racism, racial discrimination, xenophobia and related intolerance, and that Africans and people of African descent, Asians and people of Asian descent and indigenous peoples were victims of these acts and continue to be victims of their consequences (emphasis added);

'We recognize that colonialism has led to racism, racial discrimination, xenophobia and related intolerance, and that Africans and people of African descent, and people of Asian descent and indigenous peoples were victims of colonialism and continue to be victims of its consequences. We acknowledge the suffering caused by colonialism and affirm that, wherever and whenever it occurred, it must be condemned and its reoccurrence prevented. We further regret that the effects and persistence of these structures and practices have been among the factors contributing to lasting social and economic inequalities in many parts of the world today'.

In sum, the question of 'how far back' has no single answer. The circumstances of each historic injustice must be looked at to determine whether reparations are warranted and possible. In some instances neither the victims nor the perpetrators can be identified with any degree of certainty, nor can causality between the historic injustice and present circumstances be established. Yet, there are other cases where unjust enrichment is clear, where the immorality and even illegality of the acts at the time they were committed can be proven, and where reparation is necessary to redress the moral imbalance and restore the dignity and humanity of the victims. The task for the legal community is to identify the appropriate cases and provide the compelling arguments that will lead to the just result.

Dinah Shelton

Notre Dame Law School 